\title{
CHILDREN LEFT BEHIND: SELF-CONFIDENCE OF PUPILS IN COMPETITIVE ENVIRONMENTS
}

\author{
Miroslava Federičová \\ Filip Pertold \\ Michael L. Smith
}

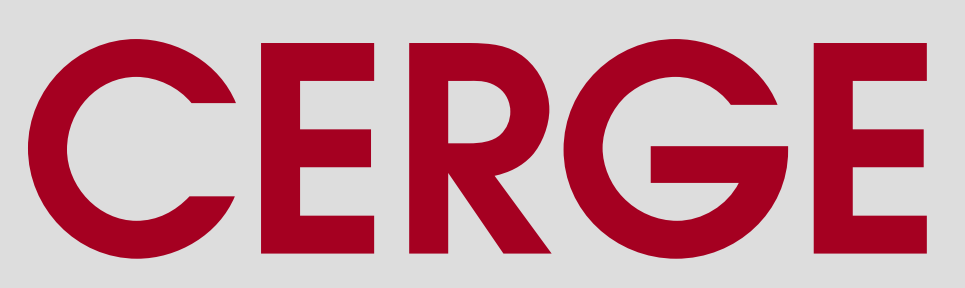




\section{Working Paper Series $\quad 574$ (ISSN 1211-3298)}

\section{Children Left Behind: Self-confidence of Pupils in Competitive Environments}

Miroslava Federičová

Filip Pertold

Michael L. Smith

CERGE-EI

Prague, November 2016 
ISBN 978-80-7343-381-9 (Univerzita Karlova, Centrum pro ekonomický výzkum a doktorské studium)

ISBN 978-80-7344-397-9 (Národohospodářský ústav AV ČR, v. v. i.) 


\title{
Children Left Behind: Self-confidence of Pupils in Competitive Environments
}

\author{
Miroslava Federičová ${ }^{1} \quad$ Filip Pertold ${ }^{2} \quad$ Michael L. Smith ${ }^{3}$
}

November 2016

Early-tracking systems naturally divide many classes of 11 years old students into two groups: students preparing for exams to enter better schools and everyone else, who decide not to compete for selective schools. Utilizing TIMSS data and a follow-up study in the Czech Republic, which has an early-tracking system similar to other European states following the German model, we show that this environment has a detrimental effect on the self-confidence of pupils in mathematics who do not apply for selective schools but have peers in their classroom who do apply. In particular, we show that girls who do not apply for selective schools experience a $11 \%$ drop in confidence in mathematics if they have four applicants among classmates and this effect is even larger if the applicants are successful in the admission process. We focus on self-confidence in mathematics as an outcome variable because the literature suggests it is directly linked to pupils' motivation to study STEM fields as well as subsequent educational achievement. Our results suggest that the decrease in selfconfidence among girls is long lasting and implies that gender gaps in self-confidence can be a result of the competitive environment of the educational system.

Keywords: early tracking, gender differences, self-confidence, inequality aversion

JEL: I21, I24, J16, Z13

\footnotetext{
${ }^{1}$ CERGE-EI, a joint workplace of Charles University and the Economics Institute of the Czech Academy of Sciences, Politickych veznu 7, 11121 Prague, Czech Republic. Supported by the Czech Science Foundation, grant no. P402/12/G130.

2 CERGE-El, a joint workplace of Charles University and the Economics Institute of the Czech Academy of Sciences, Politickych veznu 7, 11121 Prague, Czech Republic. Supported by the Czech Science Foundation, grant no. P402/12/G130.

${ }^{3}$ Corresponding author. CERGE-EI, a joint workplace of Charles University and the Economics Institute of the Czech Academy of Sciences, Politickych veznu 7, 11121 Prague, Czech Republic. Email: Michael.Smith@cergeei.cz. Phone: (+420) 737813 807. Supported by the Czech Science Foundation, grant no. 14-36154G.
} 


\section{Introduction}

Economic literature often relates gender gaps in labor market outcomes to higher male competitiveness driven by their higher confidence (Niederle \& Vesterlund, 2011). Educational research has also shown that one's self-confidence can play an important role in the choice of educational fields and performance during exams (Dean \& Fleckenstein, 2007; Kinzie, Delcourt \& Powers, 1994; Marra et al., 2009). In particular, the evidence suggests that gender differences in self-confidence contribute to girls' underperformance in math and science exams (Louis \& Mistele, 2012) and shy them away from competitive educational fields (Niederle \& Vesterlund, 2007). This is in line with social cognitive theory suggesting that self-confidence is essential for students' motivations to achieve (Bandura, 2001; Zimmerman, 2000). Although the importance of self-confidence is well recognized in the social sciences, previous literature has not addressed whether individuals' self-confidence is an inherent trait, or may be also a product of environments induced, for example, by educational systems. $^{4}$

Early tracking processes are high stakes tournaments that produce unequal outcomes in educational attainment because they sort pupils into better or worse schools, purportedly by ability (Betts, 2011; Gamoran \& Mare, 1989). In this context, track placement into a 'better' or 'selective' school means that such schools achieve higher levels of academic performance (e.g. Werfhorst \& Mijs, 2010), higher rates of college entry (Shavit, 2007), and lead to greater job prospects. While there has been conducted a substantive research on the effects of track placement on subsequent achievement, the literature has ignored how the competitive allocation process itself may impact children left behind, i.e. children who do not apply to selective schools but are nonetheless observers of the process and outcome of the competition.

\footnotetext{
${ }^{4}$ Bandura (1997) posited that self-confidence in one's own capacities was the result of observed performance and other social-psychological factors (Usher \& Pajares, 2009). Previous literature also discusses the problem of nature vs. nurture in gender differences in competitiveness (Niederle \& Vesterlund, 2010), but not the selfconfidence as such.
} 
In this paper, we present evidence using longitudinal data that the process of competitive environment induced by early tracking negatively affects pupils' self-confidence in mathematics. In particular, we show that having classmates who are applying to a selective school negatively impacts the self-confidence of those who did not apply. This effect is particularly strong for girls and in classes where classmates are successful in the admission process. Our results show that the lower confidence persists over time, and is robust to controlling for GPA, number of slots in selective schools, parental involvement in application process, class level of self-confidence or objectively measured math abilities. The decrease in confidence is also slightly stronger when parents do not want their children to apply, which is in line with the fact that parental background and decision of parents play crucial role in application process. Our findings add into the discussion about gender differences in responses to competitive environments (Gneezy, Niederle \& Rustichini, 2003; Niederle \& Vesterlund, 2010), as well as gender differences in inequality aversion, which are particularly acute in early adolescence (Fehr, Bernard \& Rockenbach, 2008; Fehr \& Schmidt, 1999).

In our set-up, children and their parents have the opportunity to decide whether to apply during the $5^{\text {th }}$ grade to a prestigious academic junior high school, attendance at which brings social prestige, higher quality academic instruction, and better educational opportunities. In fact, 90 percent of applicants in our sample report that their application decision was driven by the decision of parents. ${ }^{5}$ If children do not apply to such schools, they by default continue their studies at an elementary school until the end of compulsory education. The set-up is similar to situations where children apply for placement into classrooms for the "gifted" or other advanced placement schemes, while children who choose to not apply or who are not accepted maintain their status quo. The children left behind, who do not apply for academic track constitute in our case $87 \%$ of the school population.

\footnotetext{
${ }^{5}$ Previous evidence and our data suggest that parental background and $4^{\text {th }}$ grade GPA are the main predictors of the application decisions. It is therefore reasonable to assume that 11 year olds have a rather passive role in the decision to apply, and no decision to apply would be made without support of their parents.
} 
Our empirical strategy takes advantage of a longitudinal dataset based on the participants in the TIMSS (Trends in International Mathematics and Science Study) survey in the $4^{\text {th }}$ grade and its follow-up study CLoSE (Czech Longitudinal Study in Education) in the $5^{\text {th }}$ grade and $6^{\text {th }}$ grade. Based on this panel, we can take advantage of specific questions about pupils' self-confidence, as well as of detailed measures of academic achievement, social and parental background, and classroom characteristics. All these variables are used to control for the potential sorting of students into classes and explain a large portion of variation in preapplication self-confidence across classes. All pupils in our sample are situated in standardized, non-differentiated classrooms, with school placement based mainly on catchment area. Early in the 5th grade, these pupils then make decisions on whether to apply to academic junior high schools, each of which designs its own entrance exam specific to the school. Our follow-up panel of TIMSS participants was fielded later on in the $5^{\text {th }}$ grade, after application decisions were made and after they received notice of acceptance. Our main outcome variable is the change in self-confidence in mathematics between $4^{\text {th }}$ and $5^{\text {th }}\left(6^{\text {th }}\right)$ grades, that is, before and after the application process is complete.

We focus on the competitive allocation process because such settings may reveal different preferences in the distribution of payoffs - maximin, efficiency or fairness preferences, which has been the subject of intensive debate (Bolton \& Ockenfels, 2006; Engelmann \& Strobel, 2004; Fehr, Naef, \& Schmidt, 2006). In the related literature, child psychologists have shown that the competitive environments induce social comparisons among children that lead to negative emotional states, such as envy, gloating or taking delight of someone else misfortune (Smith \& Kim, 2007). At the age of 10, children tend to have high inequality aversion and are not willing to take spiteful decisions, which put other children into disadvantaged positions. When children lose, they feel worse about it if others win than when others also lose (Steinbeis \& Singer, 2013). This is analogical to the situation 
in early tracking environments when children, who do not apply to selective schools, for example due to the insistence of their parents for the status quo, watch their peers apply and be admitted to selective schools that offer superior educational experience and prospects. In this case, inequality aversion is not revealed as an ex ante preference, but as an emotional response to the observation of a competitive process with unequal payoffs, which is measured in terms of the reduction in self-confidence of children who are left behind from that competition.

Recent experimental research in economics suggests that there may be important gender differences in inequality aversion, but that these vary greatly by the type and specific parameters of the competitive environment (Andreoni \& Vesterlund, 2001; Eagly \& Wood, 1999; Eckel \& Grossman, 1998; Feingold, 1994). The literature seems consistent in finding that, already at an early age, boys respond more positively than girls to winner-take-all tournaments, such as the desire to compete, even if there may not be gender differences in actual performance (Croson \& Gneezy, 2009). The literature has also found that while preferences for egalitarian distributions increase with age among both girls and boys and have similar propensities at age 7-8, boys are less averse against disadvantageous inequality to ingroup members, such as classmates, compared to out-group members, while girls' degree of inequality aversion does not vary by in-group or out-group status (Fehr, Bernhard, \& Rockenbach, 2008).

Lastly, our study on changes in self-confidence as a responsive form of inequality aversion is also motivated by the role of self-confidence as a non-cognitive skill that can significantly affect future academic achievement and employability (Andrews \& Higson, 2008; Norman \& Hyland, 2003; Pool \& Sewell, 2007). There are also gender differences in the development of soft skills at an early age, with girls exhibiting more responsibility than boys (Montgomery, 2005). Heckman and Kautz (2012) have argued strongly in favour of the 
long-term benefits of soft skills, but they operationalize soft skills uni-dimentionally (Big 5 personality traits), without taking into account self-confidence and related concepts. Our study contributes to this literature by examining how competitive environments in a common institutional setting can contribute to changes in self-confidence, and thus the formation of one type of soft skill during the developmental stage of early adolescence.

In the following, we overview the institutional context of our study and the key variables. The empirical strategy specifies the baseline model tested, the results of which are then reported along with empirical extensions that enable us to differentiate the roles of the competitive process and outcome of competition on self-confidence, as well as the persistence of the effect in the 6th grade. The conclusion assesses the robustness of the results and points to future directions for follow-up studies.

\section{Institutional background and data}

The Czech Republic as well as many other, especially Central European, countries provide pupils with the possibility to transfer to elite junior high schools (8-year gymnasia) after the completion of primary education in the $5^{\text {th }}$ grade, i.e. usually around the age of 11 . This system of early tracking is based on the German model of education, which has been a focal point of research on educational efficiency and inequality (Gamoran \& Mare, 1998; Hanushek, 2006; Heubert \& Hauser, 1998; Woessmann, 2010) and which some scholars regard as the most stratified in the world (Buchmann \& Park, 2009; Phillips, 2000). This model is characterized by a highly differentiated system of secondary education offering vocationally specific apprentice programs, which are dead-end tracks that provide pupils with focused labor market opportunities but not credentials needed for tertiary education. In order to avoid ending up in dead-end tracks, and thus limited future educational and labor market prospects, many Czech children (and their parents) aim to enter elite junior high schools at the earliest opportunity, i.e. the application process in the $5^{\text {th }}$ grade. 
This early-tracking school system can be contrasted with comprehensive school systems, such as in Finland, in which all pupils are educated in one school track up to the age of 15 or 16, or other standardized school systems, such as in the United States, England, or South Korea, where primary and middle schools (up to the age of 15 or 16) offer relatively standardized curricula for all students. In the early-tracking school system, since the allocation to the academic track is non-random, early tracking introduces selection in the schooling process at very early age, particularly by family background (Betts, 2011; Brunello $\&$ Checchi, 2007). When compared to the Taiwanese system of education, which is relatively stratified but lacks dead-end tracks, the Czech educational system produces systematically larger inequalities in educational attainment by family background, particularly in terms of complete secondary education (Authors, 2016).

This paper focuses on the Czech school system in which pupils in the $5^{\text {th }}$ grade have an option to apply to academic junior high schools. These are widely regarded as the most prestigious public schools in the country. Acceptance into these schools is highly predictive of future university attendance and high occupational and income status, and is strongly determined by family background (Greger, 2015). Typically, slightly less than $20 \%$ of pupils apply to these schools and more than half are admitted, such that about a tenth of former fifth graders end up in this academic track in the next school year. Pupils who did not apply or were not admitted continue in the same track up to the end of lower secondary education, i.e. up to the $9^{\text {th }}$ grade. Pupils who apply have to usually pass the high-stake entrance exams that are administered at the end of April. The admission decision is then based on results from entrance exams and on the primary school grade point average (GPA). Although the application decision is announced before mid-March, there is evidence that pupils start preparing for entrance exams, usually though demanding private courses, already at the beginning of the school year in September. The authors (2014) show that half of all pupils 
who applied to academic junior high schools dedicated some time almost every day to preparing for entrance exams in the semester beforehand. Thus, at least 6 months before the entrance exams, fifth graders are divided into two groups: those who are applying, and thus preparing to take the entrance exams, and those who are not.

To examine the effect of this class division on students' self-confidence, we explore Czech panel data collected before and after the selection process in the $5^{\text {th }}$ grade. The panel data consists of two datasets, the international TIMSS survey held in 2011 and its follow-up study, CLoSE (Czech Longitudinal Study in Education). TIMSS tests a nationally representative sample of pupils in the $4^{\text {th }}$ grade in math and science in four year cycles. Together with these test scores, TIMSS collects school, parental, and student questionnaires that provide detailed information about pupils' school and socio-economic background as well as their perception of their own study aptitudes. The sample of Czech fourth graders tested by TIMSS in 2011 then completed the CLoSE survey in the $5^{\text {th }}$ grade, which focused on the application, preparation and admission process of pupils. Of 4,578 students TIMSS 2011, 3,681 students were followed up by the CLoSE survey in the $5^{\text {th }}$ grade $^{6}$.

\section{Self-confidence measure}

The challenging process of preparing for and dealing with the prospects of success or failure in high-stakes entrance exams affects not only those who applied but all students in the class. Different degrees of competition, indicated by the number of students in each class taking part in the entrance exams, can alter self-confidence of those students who are left behind. The surveys in both the $4^{\text {th }}$ and the $5^{\text {th }}$ grades asked pupils to self-assess their own performance in mathematics (i.e. Do well in math). In the $4^{\text {th }}$ grade, this is indicated by pupils' responses to the statement "I usually do well in mathematics" and in the $5^{\text {th }}$ grade to the statement "I was always good at math."The response categories to these statements in both

\footnotetext{
${ }^{6}$ A sub-sample of the $5^{\text {th }}$ graders - i.e. 2837 students - were further interviewed in the subsequent school years. To examine the long-term effects of tracking, we provide also the main descriptive statistics for $6^{\text {th }}$ graders.
} 
surveys are based on the same 4-point scale: Agree a lot=1, Agree a little=2, Disagree a little $=3$, and Disagree a lot $=4$.

Table 1 presents the means from both TIMSS and CLoSE of pupils' self-confidence in the $4^{\text {th }}, 5^{\text {th }}$, and $6^{\text {th }}$ grades by gender and the competitive level of the class (i.e. the number of applicants per class). Since we are interested in how the competitive environment impacts pupils left behind, these statistics focus on the self-confidence only of those pupils who did not apply. Between the $4^{\text {th }}$ and $5^{\text {th }}$ grades, the means in self-confidence increase, indicating a decline in pupils' self-confidence. This drop in self-confidence also continues in the $6^{\text {th }}$ grade. Table 1 further indicates that girls not only have lower self-confidence in math than boys in the 4th grade (a trend common in the majority of countries participating in TIMSS), but they also experience a larger decline between the $4^{\text {th }}$ and $5^{\text {th }}$ grades that leads to even greater gender differences in self-confidence in the $5^{\text {th }}$ grade.

\section{Table 1}

Means of the self-confidence measure by gender and the number of applicants in the classroom, only for girls and boys who did not apply (using individual weights)

\begin{tabular}{lllllll|lcccccc}
\hline \multicolumn{1}{c}{ Girls } & \multicolumn{1}{c}{ Number of applicants in classroom } & \multicolumn{8}{c}{ Number of applicants in classroom } \\
& \multicolumn{1}{c}{0} & 1 & 2 & 3 & 4 & $>5$ & 0 & 1 & 2 & 3 & 4 & $>5$ \\
\hline $4^{\text {th }}$ & 1.79 & 1.57 & 1.83 & 1.88 & 1.89 & 1.92 & 1.57 & 1.61 & 1.66 & 1.66 & 1.58 & 1.71 \\
grade & $(.810)$ & $(.747)$ & $(.905)$ & $(.790)$ & $(.881)$ & $(.822)$ & $(.747)$ & $(.760)$ & $(.808)$ & $(.877)$ & $(.692)$ & $(.827)$ \\
& & & & & & & & & & & & \\
$5^{\text {th }}$ & 2.27 & 2.29 & 2.39 & 2.39 & 2.38 & 2.46 & 1.97 & 1.95 & 1.87 & 2.04 & 1.84 & 2.10 \\
grade & $(.883)$ & $(.824)$ & $(.858)$ & $(.839)$ & $(.798)$ & $(.866)$ & $(.836)$ & $(.850)$ & $(.765)$ & $(.982)$ & $(.736)$ & $(.901)$ \\
& & & & & & & & & & & & \\
$6^{\text {th }}$ & 2.26 & 2.22 & 2.34 & 2.27 & 2.33 & 2.33 & 1.89 & 1.81 & 1.94 & 1.85 & 1.80 & 2.13 \\
grade & $(.901)$ & $(.843)$ & $(.860)$ & $(.844)$ & $(.912)$ & $(.885)$ & $(.875)$ & $(.775)$ & $(.864)$ & $(.921)$ & $(.733)$ & $(.994)$ \\
\hline $\mathrm{N}$ & 284 & 235 & 168 & 186 & 156 & 369 & 330 & 270 & 187 & 197 & 159 & 345 \\
\hline
\end{tabular}



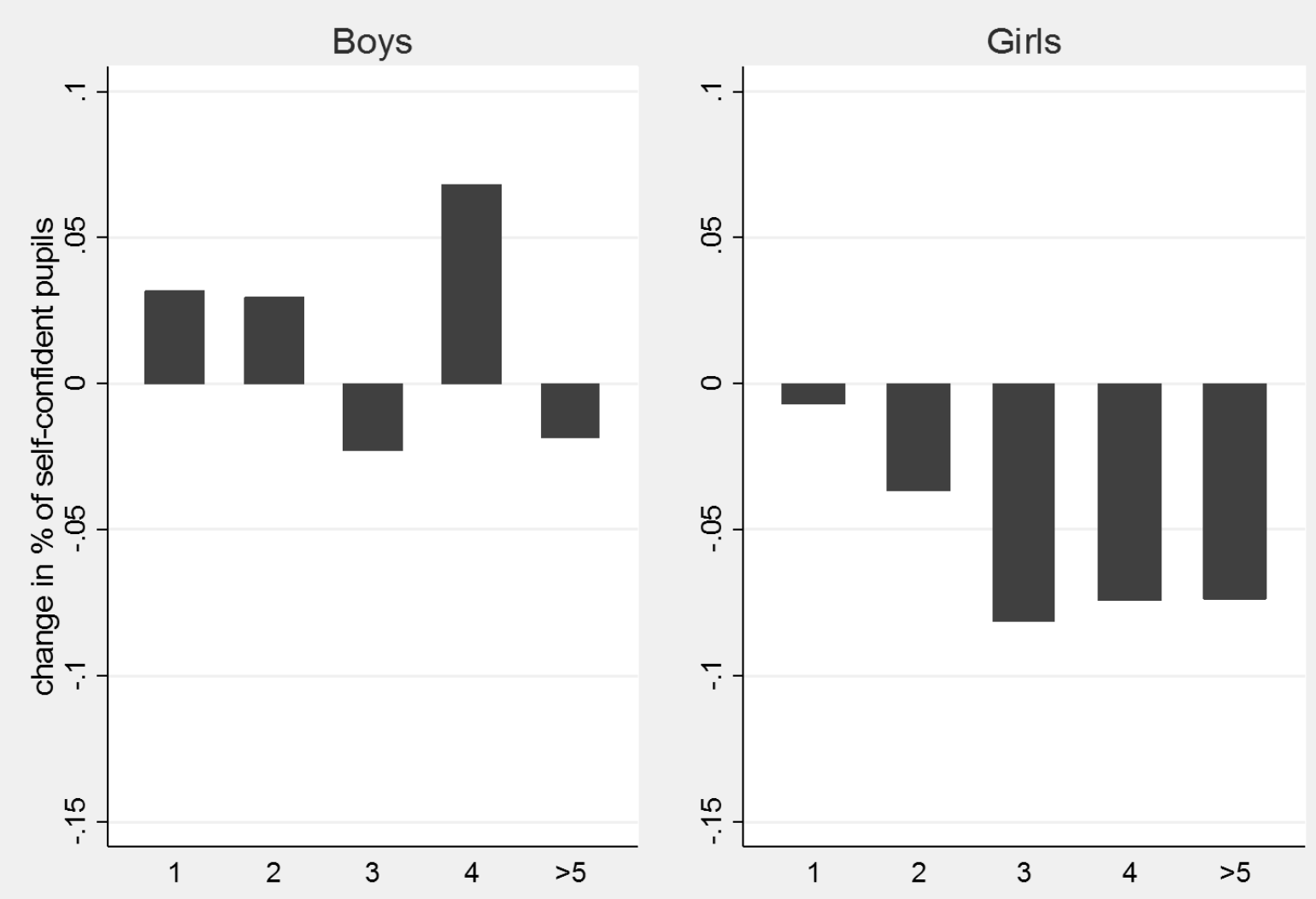

\section{Figure 1}

Change in self-confidence of pupils who did not apply with respect to the change in classes with no applicants, by the number of applicants in class

To facilitate the interpretation of results, in the empirical analysis we converted the self-confidence measure into a dichotomous variable indicating low or high levels of selfconfidence (any agreement with the self-confidence question was coded as 0 , any disagreement as 1). This transformation enables us to classify those who changed their selfassessment from high to low between the $4^{\text {th }}$ and $5^{\text {th }}$ grades as negative switchers of selfconfidence. Figure 1 depicts the change in pupils' self-confidence between the $4^{\text {th }}$ and $5^{\text {th }}$ grades with respect to the degree of change in classes with no applicants. For boys, the data suggests there is no change in self-confidence by the competitive level of the class. However, girls in classes with more than two applicants experience a decline in their self-confidence by about 8 p.p. relative to girls in classes with no applicants.

Regarding the number of admitted pupils in class, Figure 2 depicts the change in selfconfidence across classes with different numbers of admitted pupils in comparison to those 
classes in which no one was admitted, and hence, no one is leaving the class 7 . Although boys in classes with a higher number of admitted pupils do not statistically differ in self-confidence with respect to boys in classes with no admitted classmates, girls seem to be prone to declines in their self-confidence according to the number of admitted pupils in class.

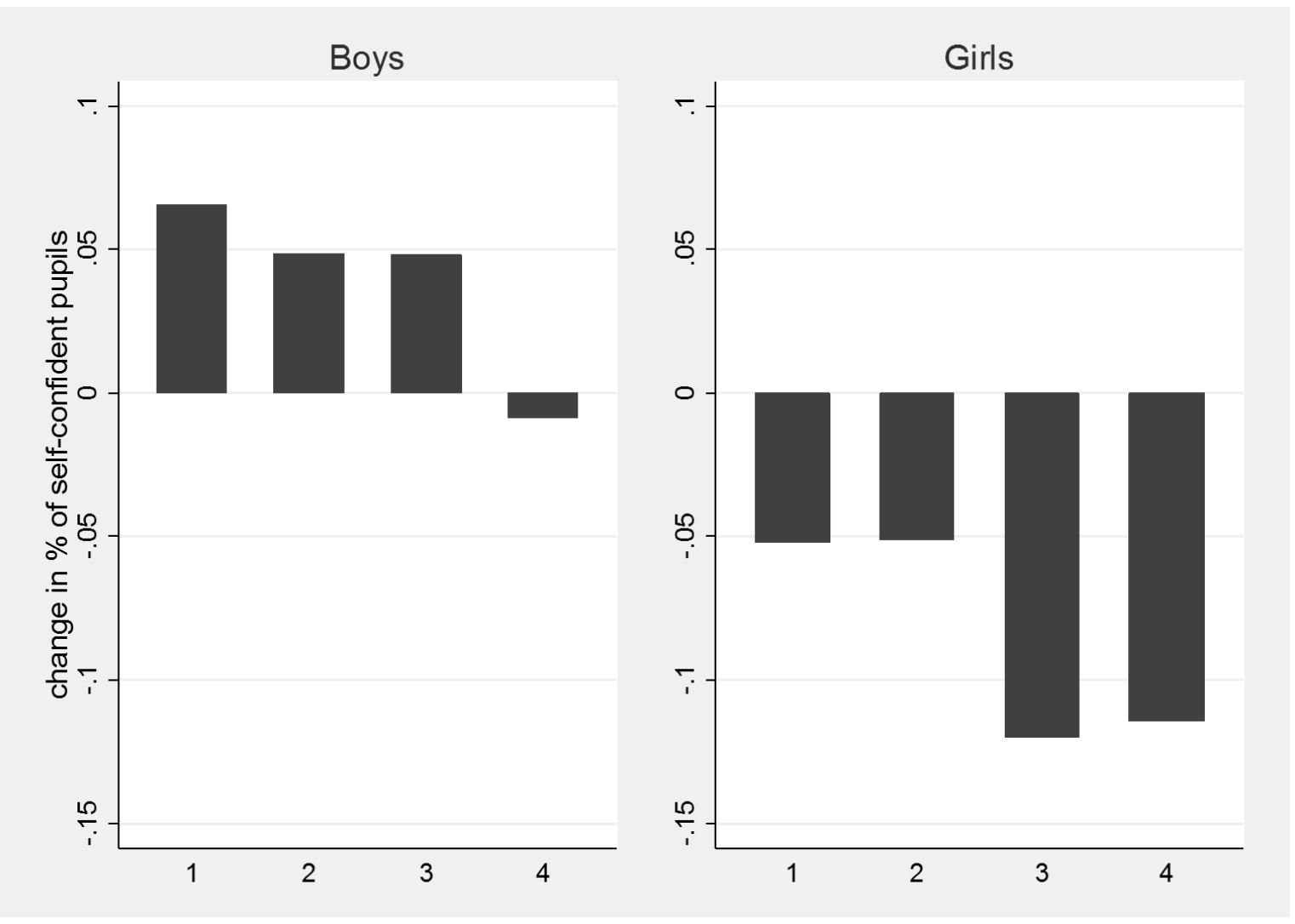

Figure 2

Relative change in the self-confidence of pupils who did not apply (normalized by the change in classes with no admitted pupils), by the number of admitted pupils in the class

\section{Assessment data}

Two academic assessment measures are available in the data: the math test score ${ }^{8}$ collected in the $4^{\text {th }}$ grade by TIMSS, and the GPA ${ }^{9}$ that pupils received in the $4^{\text {th }}$ and $5^{\text {th }}$ grades. Descriptive statistics of these measures - as well as of other individual and class

\footnotetext{
${ }^{7}$ Here, we refer to the loss of classmates to selective academic junior high schools. Pupils can also experience the loss of classmates e.g. when they move to a different city, but because such changes are few and heterogeneous, we do not include them in our analysis.

${ }^{8}$ The math test score from TIMSS is normalized to a mean of 0 and a standard deviation of 1.

${ }^{9}$ The measure of GPA is constructed as an average of final grades from Mathematics, the Czech language and other foreign language. In the Czech Republic, grades are distributed on a 5-point scale from 1 - the best grade - to 5 .
} 
characteristics - are presented in Table 2, which shows that boys outperform girls in the math test score by nearly 0.2 standard deviations, while girls receive better grades than boys in math and in the overall GPA in both the $4^{\text {th }}$ and $5^{\text {th }}$ grades. Pupils' socio-economic background - measured by the share of pupils with parents with a university education - is evenly distributed for boys and girls. Regarding the selection process, on average 3 pupils in each class apply to academic junior high schools and almost 2 pupils are admitted. Nonapplying girls experience a slightly more competitive environment than boys in terms of the number of applicants and the success rate of their classmates. Lastly, a greater share of girls report that their parents did not want them to apply, possibly due to cultural norms, financial costs, risk of failure, prevention of stress, etc. 
Table 2

Descriptive statistics of individual characteristics by gender, whole sample

\begin{tabular}{|c|c|c|c|}
\hline & All & Girls & Boys \\
\hline$\%$ of boys in own class & 51.6 & 47.5 & 55.4 \\
\hline Self-confidence $-5^{\text {th }}$ grade $(\mathrm{LHS})$ & $\begin{array}{l}.70 \\
(.459)\end{array}$ & $\begin{array}{l}.62 \\
(.486)\end{array}$ & $\begin{array}{l}.77 \\
(.418)\end{array}$ \\
\hline Self-confidence $-4^{\text {th }}$ grade & $\begin{array}{l}.86 \\
(.343)\end{array}$ & $\begin{array}{l}.84 \\
(.369)\end{array}$ & $\begin{array}{l}.89 \\
(.315)\end{array}$ \\
\hline Age & $\begin{array}{l}10.37 \\
(.413)\end{array}$ & $\begin{array}{l}10.30 \\
(.386)\end{array}$ & $\begin{array}{l}10.44 \\
(.426)\end{array}$ \\
\hline Math score (see footnote 5) & $0(1)$ & $\begin{array}{l}-.090 \\
(.984)\end{array}$ & $\begin{array}{l}.085 \\
(1.008)\end{array}$ \\
\hline GPA -4 th grade (see footnote 6 ) & $\begin{array}{l}1.63 \\
(.653)\end{array}$ & $\begin{array}{l}1.54 \\
(.599)\end{array}$ & $\begin{array}{l}1.71 \\
(.689)\end{array}$ \\
\hline GPA -5 th grade (see footnote 6 ) & $\begin{array}{l}1.86 \\
(.774)\end{array}$ & $\begin{array}{l}1.74 \\
(.731)\end{array}$ & $\begin{array}{l}1.97 \\
(.798)\end{array}$ \\
\hline Math grade-4th & $\begin{array}{l}1.59 \\
(.732)\end{array}$ & $\begin{array}{l}1.57 \\
(.705)\end{array}$ & $\begin{array}{l}1.61 \\
(.756)\end{array}$ \\
\hline Math grade- 5 th & $\begin{array}{l}1.81 \\
(.855)\end{array}$ & $\begin{array}{l}1.78 \\
(.820)\end{array}$ & $\begin{array}{l}1.84 \\
(.886)\end{array}$ \\
\hline Father - university education & $\begin{array}{l}18.4 \% \\
(38.7)\end{array}$ & $\begin{array}{l}17.7 \\
(38.2)\end{array}$ & $\begin{array}{l}18.9 \\
(39.2)\end{array}$ \\
\hline Mother - university education & $\begin{array}{l}14.8 \\
(35.5)\end{array}$ & $\begin{array}{l}14.6 \\
(35.3)\end{array}$ & $\begin{array}{l}15.0 \\
(35.7)\end{array}$ \\
\hline Learn quickly math -4 th grade & $\begin{array}{l}1.88 \\
(.918)\end{array}$ & $\begin{array}{l}2.01 \\
(.931)\end{array}$ & $\begin{array}{l}1.76 \\
(.888)\end{array}$ \\
\hline Learn quickly science -4 th grade & $\begin{array}{l}1.92 \\
(.898)\end{array}$ & $\begin{array}{l}1.87 \\
(.854)\end{array}$ & $\begin{array}{l}1.96 \\
(.936)\end{array}$ \\
\hline Do well science -4 th grade & $\begin{array}{l}1.72 \\
(.809)\end{array}$ & $\begin{array}{l}1.69 \\
(.765)\end{array}$ & $\begin{array}{l}1.74 \\
(.848)\end{array}$ \\
\hline Enjoy math - 4th grade & $\begin{array}{l}1.84 \\
(.956)\end{array}$ & $\begin{array}{l}1.91 \\
(.948)\end{array}$ & $\begin{array}{l}1.77 \\
(.958)\end{array}$ \\
\hline Class size & $\begin{array}{l}17.6 \\
(5.4)\end{array}$ & $\begin{array}{l}17.7 \\
(5.3)\end{array}$ & $\begin{array}{l}17.4 \\
(5.4)\end{array}$ \\
\hline Number of applicants in own class & 3.0 & 3.2 & 2.9 \\
\hline Number of admitted pupils in own class & 1.9 & 2.0 & 1.8 \\
\hline Parents didn't want me to apply (\% of non-applicants) & 56.9 & 58.1 & 55.8 \\
\hline $\mathrm{N}$ & 3681 & 1817 & 1864 \\
\hline
\end{tabular}

Note: Standard deviations are in parenthesis. 


\section{Empirical strategy}

In our estimation, we employ the level of self-confidence in the $5^{\text {th }}$ grade as our main left hand side variable. The variable is dichotomous, referring to high or low levels of selfconfidence in mathematics. The key right hand side variables are set of dichotomous dummies indicating the number of classmates applying to junior academic high schools. For subsequent analyses, we also constructed similar dummies for whether the number of admitted pupils was $0,1,2, \ldots 5$. The main control variables are the level of self-confidence in the $4^{\text {th }}$ grade, GPA in the $4^{\text {th }}$ grade, the TIMSS math score indicating math ability, parental education (two dummies for whether each completed tertiary education), gender, and age. We also control for commensurate classroom characteristics (class averages in $4^{\text {th }}$ grade TIMSS math scores, $4^{\text {th }}$ grade GPA, and $4^{\text {th }}$ grade self-confidence, and the number of pupils in the class). Lastly, we also include as controls additional attitudinal variables ("other indexes" in Table 3) relating to math and science: whether the pupil reports doing well in science, learning things quickly in science, learning quickly in math, and enjoying math.

One identification issue of our setup is the degree to which our control variables can explain the potential sorting of students into classes and schools, where change in the number of applied students and change in the self-confidence can be driven by common unobserved factors. Although we cannot directly test for this sorting, we analysed to what extent our control variables explain variation in the number of applied students in the class. As shown in Appendix 1, we explain $40 \%$ of the variation and more importantly, the unexplained part of the number of applicants in a given class is not correlated with class level self-confidence. This suggests that our control variables are able to capture most of ex-ante association between the pre-treatment level of self-confidence and the number of applicants across classes. The second identification issue is what mechanism stands behind the effect of the number of applicants in a class on the change in self-confidence. We discuss several potential 
mechanisms in the results, such as the role of parents in application decision or a change in GPA.

For our analysis, we employ both probit and linear probability models, and compare the coefficients as a matter of robustness. Because we find that the results for both models are substantively identical, we mainly report the LPM results due to their ease of interpretation and the computational tractability of the model. The model can thus be expressed in the simple form:

$$
y_{i, t, c}=\alpha+\beta y_{i, t-1, c}+\# \text { applied }_{t, c}+X_{i, c}+X_{c}+\varepsilon_{i, t, c}
$$

where the self-confidence $y$ of pupils $i$ in classrooms $c$ in grade $t$ (i.e. the $5^{\text {th }}$ grade) is predicted by those pupils' self-confidence in the $4^{\text {th }}$ grade $(t-1)$, the number of pupils applying to the selective schools in the $5^{\text {th }}$ grade (\#applied), the vectors of both individual and family characteristics of the pupil as well as classroom characteristics $X$, and the error term. We also run the model separately for boys and girls, as well as together, in which case gender is included in the model.

\section{Results}

Our main results are summarized in Table 3 . In order to measure the change in selfconfidence for those who did not apply to academic junior high schools, we apply firstly the linear probability model presented in the first three columns. Controlling for the individual and average class abilities in math, as well as other individual characteristics described above, Column 1 reveals that self-confidence declines with the increasing number of applicants in class. Thus, those pupils who did not apply and experience high level of competition in their class (i.e. class with 5 and more pupils who applied) have on average a $7 \%$ higher probability of experiencing a decline in self-confidence compared to pupils in classes with no applicants. Dividing pupils by gender in Columns 2 and 3, the results indicate that this decline in selfconfidence is experienced by girls in all modelled situations where there are at least three 
applicants in the classroom, whereas the competitive level of class seems to have no measurable effect on the self-confidence of boys. For girls, the probability of experiencing a decline in self-confidence between classes with 3 and more applicants and no applicants is about $10 \%$.

The individual characteristics used as control variables in the model have the expected signs in all regressions (see Appendix 2): self-confidence and math score in the 4th grade positively affect the self-confidence in the following grades, whereas higher grade average in the 4th grade decreases the self-confidence; boys are more likely to report self-confidence than girls, and parents education seems to have no impact on pupils' self-confidence.

Table 3

Change in self-confidence of pupils who did not apply, LPM and marginal effects after Probit

\begin{tabular}{|c|c|c|c|c|c|c|}
\hline \multirow{2}{*}{ Self-confidence $\left(5^{\text {th }}\right.$ grade $)$} & \multicolumn{3}{|c|}{ LPM } & \multicolumn{3}{|c|}{ Probit } \\
\hline & All & Girls & Boys & All & Girls & Boys \\
\hline \multicolumn{7}{|l|}{$\begin{array}{l}\text { Number of applicants } \\
\text { ( } 0 \text { as control group) }\end{array}$} \\
\hline 1 & $\begin{array}{l}-0.014 \\
(0.027)\end{array}$ & $\begin{array}{l}-0.024 \\
(0.042)\end{array}$ & $\begin{array}{l}-0.006 \\
(0.035)\end{array}$ & $\begin{array}{l}-0.014 \\
(0.027)\end{array}$ & $\begin{array}{l}-0.030 \\
(0.041)\end{array}$ & $\begin{array}{l}-0.003 \\
(0.034)\end{array}$ \\
\hline 2 & $\begin{array}{l}-0.016 \\
(0.030)\end{array}$ & $\begin{array}{l}-0.064 \\
(0.046)\end{array}$ & $\begin{array}{c}0.036 \\
(0.039)\end{array}$ & $\begin{array}{l}-0.016 \\
(0.029)\end{array}$ & $\begin{array}{l}-0.069 \\
(0.045)\end{array}$ & $\begin{array}{c}0.034 \\
(0.037)\end{array}$ \\
\hline 3 & $\begin{array}{l}-0.060^{* *} \\
(0.029)\end{array}$ & $\begin{array}{l}-0.090^{* *} \\
(0.044)\end{array}$ & $\begin{array}{l}-0.034 \\
(0.038)\end{array}$ & $\begin{array}{l}-0.058^{* *} \\
(0.029)\end{array}$ & $\begin{array}{l}-0.087^{* *} \\
(0.043)\end{array}$ & $\begin{array}{l}-0.039 \\
(0.038)\end{array}$ \\
\hline 4 & $\begin{array}{l}-0.032 \\
(0.032)\end{array}$ & $\begin{array}{l}-0.115^{* *} \\
(0.049)\end{array}$ & $\begin{array}{c}0.043 \\
(0.041)\end{array}$ & $\begin{array}{l}-0.033 \\
(0.031)\end{array}$ & $\begin{array}{l}-0.115^{* *} \\
(0.048)\end{array}$ & $\begin{array}{c}0.040 \\
(0.039)\end{array}$ \\
\hline 5 or more & $\begin{array}{c}-0.069^{* * * *} \\
(0.026)\end{array}$ & $\begin{array}{c}-0.085^{* *} \\
(0.039)\end{array}$ & $\begin{array}{l}-0.056 \\
(0.035)\end{array}$ & $\begin{array}{c}-0.071^{* * * *} \\
(0.026)\end{array}$ & $\begin{array}{c}-0.088^{* *} \\
(0.039)\end{array}$ & $\begin{array}{l}-0.060^{*} \\
(0.035)\end{array}$ \\
\hline Individual characteristics & Yes & Yes & Yes & Yes & Yes & Yes \\
\hline Class characteristics & Yes & Yes & Yes & Yes & Yes & Yes \\
\hline Other Indexes ( $4^{\text {th }}$ grade $)$ & Yes & Yes & Yes & Yes & Yes & Yes \\
\hline$N$ & 2479 & 1216 & 1263 & 2479 & 1216 & 1263 \\
\hline$R^{2}$ & 0.265 & 0.255 & 0.248 & & & \\
\hline
\end{tabular}

Using the same identification strategy, the second half of Table 3 summarizes the results of marginal effects according to the Probit model. In the substantively same way as the linear probability model, the results show a significant decline in the self-confidence of pupils with the increasing level of competition in the class. Again, girls seem to be particularly 
affected by this class environment. This decline in self-confidence may be triggered by several different mechanisms, such as the natural increase in competition in class, the leaving of classmates/friends from class, a more demanding teacher policy due to entrance exams to academic junior high schools (especially in classrooms where more pupils are preparing to apply for those exams), etc. Our subsequent models are designed to tease out which of these mechanisms are driving our results, and to detect the qualities of pupils that are mostly likely to be affected by this early-tracking school policy. As mentioned above, because LPM and probit models yield to similar results, for simplicity we further present the results only for LPM.

We continue by differentiating the effect of the class environment in which peers are preparing for the demanding entrance exams, and the effect of payoffs, caused by the loss of classmates at the end of the school year due to their success in the entrance exams. The coefficients for payoffs can be potentially seen as expressions of inequality aversion, as it is a direct response to the future sorting of classmates into selective and status quo schools. 


\section{Table 4}

Change in self-confidence of pupils who did not apply, controlling for the number of applicants and admitted pupils in the classroom

\begin{tabular}{|c|c|c|c|}
\hline Self-confidence $\left(5^{\text {th }}\right.$ grade $)$ & $\begin{array}{l}(1) \\
\text { All }\end{array}$ & $\begin{array}{c}(2) \\
\text { Girls }\end{array}$ & $\begin{array}{c}(3) \\
\text { Boys }\end{array}$ \\
\hline \multicolumn{4}{|l|}{$\begin{array}{l}\text { Number of applicants } \\
\text { ( } 0 \text { as control group) }\end{array}$} \\
\hline 1 & $\begin{array}{l}-0.017 \\
(0.036)\end{array}$ & $\begin{array}{c}0.049 \\
(0.056)\end{array}$ & $\begin{array}{l}-0.080^{*} \\
(0.046)\end{array}$ \\
\hline 2 & $\begin{array}{l}-0.034 \\
(0.043)\end{array}$ & $\begin{array}{c}0.021 \\
(0.068)\end{array}$ & $\begin{array}{l}-0.076 \\
(0.055)\end{array}$ \\
\hline 3 & $\begin{array}{l}-0.056 \\
(0.043)\end{array}$ & $\begin{array}{c}0.013 \\
(0.066)\end{array}$ & $\begin{array}{l}-0.134 * * \\
(0.057)\end{array}$ \\
\hline 4 & $\begin{array}{l}-0.030 \\
(0.047)\end{array}$ & $\begin{array}{l}-0.004 \\
(0.073)\end{array}$ & $\begin{array}{l}-0.059 \\
(0.060)\end{array}$ \\
\hline 5 & $\begin{array}{l}-0.044 \\
(0.046)\end{array}$ & $\begin{array}{c}0.039 \\
(0.071)\end{array}$ & $\begin{array}{l}-0.124^{* *} \\
(0.061)\end{array}$ \\
\hline \multicolumn{3}{|l|}{$\begin{array}{l}\text { Number of admitted pupils } \\
\text { ( } 0 \text { as control group) }\end{array}$} & $\begin{array}{l}0.104^{* *} \\
(0.044)\end{array}$ \\
\hline 2 & $\begin{array}{c}0.034 \\
(0.041)\end{array}$ & $\begin{array}{l}-0.084 \\
(0.063)\end{array}$ & $\begin{array}{c}0.149^{* * *} \\
(0.054)\end{array}$ \\
\hline 3 & $\begin{array}{l}-0.023 \\
(0.042)\end{array}$ & $\begin{array}{c}-0.139^{* *} \\
(0.065)\end{array}$ & $\begin{array}{l}0.096^{*} \\
(0.055)\end{array}$ \\
\hline 4 & $\begin{array}{l}-0.034 \\
(0.051)\end{array}$ & $\begin{array}{l}-0.136^{*} \\
(0.079)\end{array}$ & $\begin{array}{c}0.064 \\
(0.066)\end{array}$ \\
\hline 5 & $\begin{array}{l}-0.050 \\
(0.051)\end{array}$ & $\begin{array}{l}-0.139^{*} \\
(0.076)\end{array}$ & $\begin{array}{c}0.026 \\
(0.068)\end{array}$ \\
\hline Individual characteristics & Yes & Yes & Yes \\
\hline Class characteristics & Yes & Yes & Yes \\
\hline Other Indexes ( $4^{\text {th }}$ grade $)$ & Yes & Yes & Yes \\
\hline$N$ & 2479 & 1216 & 1263 \\
\hline$R^{2}$ & 0.267 & 0.259 & 0.255 \\
\hline
\end{tabular}

In the regression framework, we add dummy variables representing the number of successful applicants to the model summarized in Table 3. This approach enables us to differentiate two mechanisms of change in self-confidence due to the competitive process (i.e. classmates preparing for exams) and the effect of classmates leaving the class. Table 4 summarizes these results. After controlling for both the number of admitted pupils and pupils in the classroom who applied, the overall effects for boys and girls together in the first column are insignificant. This, however, masks key gender differences expressed in Columns 2 and 3. Girls seem to be unaffected by the number of applicants in their class, but their self- 
confidence does significantly decline with the increasing number of classmates that are leaving the class. That is, girls are more inequality averse: they are more likely to experience declines in self-confidence due to the loss of peers. For boys, the estimated coefficients go in the opposite direction: they are negative for the number of applicants and positive for admitted classmates. However, in many predicted scenarios (e.g. one applicant in the class, who was accepted), the coefficients cancel each other out, such that the net effect in most scenarios is negligible, or zero.

\section{Change in GPA}

Another mechanism possibly contributing to reduced self-confidence among pupils in classes with a higher number of applicants may be the change in grades given to students between the $4^{\text {th }}$ and $5^{\text {th }}$ grades. For example, the more demanding class environment imposed by teachers in classes with a higher number of applicants - and hence a higher number of pupils preparing for high-stakes entrance exams - may naturally cause a drop in grades of those who did not apply as they are excluded from the preparation process for these exams. Pupils usually dedicate effort and extra time to prepare for the exams, which would likely boost their grades. This change in grades may also negatively impact the self-confidence of those left behind. Alternatively, however, pupils who are disappointed that they were discouraged from applying might change their effort, and their GPA can drop. In both cases, GPA can potentially explain a part of the decline in self-confidence.

To test for that, we include in our main empirical specification the change in math grades between those years. The reference group is constituted by pupils who improved their grades from the $4^{\text {th }}$ to the $5^{\text {th }}$ year. The results are presented in Table 5. Although the drop in math grades between the $4^{\text {th }}$ and $5^{\text {th }}$ year induces the significant drop in self-confidence, controlling for this change in GPA does not diminish the effect of competition in class. In other words, the negative effect of the number of applicants in the classroom on the level of 
self-confidence is not influenced by the change in GPA, representing here the more demanding teacher policy or other discouragement leading to the drop in GPA.

Table 5

Change in self-confidence of pupils who did not apply, the change in GPA

\begin{tabular}{|c|c|c|c|}
\hline Self-confidence $\left(5^{\text {th }}\right.$ grade $)$ & (1) & $\begin{array}{c}(2) \\
\text { Girls }\end{array}$ & $\begin{array}{l}(3) \\
\text { Boys }\end{array}$ \\
\hline \multicolumn{4}{|l|}{ Number of applicants ( 0 as control group) } \\
\hline 1 & $\begin{array}{l}-0.019 \\
(0.027)\end{array}$ & $\begin{array}{l}-0.034 \\
(0.043)\end{array}$ & $\begin{array}{l}-0.007 \\
(0.034)\end{array}$ \\
\hline 2 & $\begin{array}{l}-0.011 \\
(0.030)\end{array}$ & $\begin{array}{l}-0.062 \\
(0.046)\end{array}$ & $\begin{array}{c}0.045 \\
(0.039)\end{array}$ \\
\hline 3 & $\begin{array}{l}-0.064^{* *} \\
(0.029)\end{array}$ & $\begin{array}{c}-0.092^{* *} \\
(0.044)\end{array}$ & $\begin{array}{l}-0.040 \\
(0.037)\end{array}$ \\
\hline 4 & $\begin{array}{l}-0.038 \\
(0.031)\end{array}$ & $\begin{array}{c}-0.129^{* * *} \\
(0.049)\end{array}$ & $\begin{array}{c}0.046 \\
(0.041)\end{array}$ \\
\hline 5 & $\begin{array}{c}-0.072^{* * *} \\
(0.026)\end{array}$ & $\begin{array}{c}-0.083^{* *} \\
(0.040)\end{array}$ & $\begin{array}{l}-0.065^{*} \\
(0.035)\end{array}$ \\
\hline \multicolumn{4}{|l|}{$\begin{array}{l}\text { Change in math grade (controlling for } \\
\text { better grade in the } 5^{\text {th }} \text { grade) }\end{array}$} \\
\hline No change in math grade & $\begin{array}{c}-0.126^{* * *} \\
(0.033)\end{array}$ & $\begin{array}{l}-0.094^{*} \\
(0.050)\end{array}$ & $\begin{array}{c}-0.162^{* * *} \\
(0.043)\end{array}$ \\
\hline Worse math grade in the $5^{\text {th }} \mathrm{gr}$ & $\begin{array}{c}-0.247^{* * *} \\
(0.035)\end{array}$ & $\begin{array}{c}-0.228^{* * *} \\
(0.053)\end{array}$ & $\begin{array}{c}-0.277^{* * *} \\
(0.045)\end{array}$ \\
\hline Individual characteristics & Yes & Yes & Yes \\
\hline Class characteristics & Yes & Yes & Yes \\
\hline Other Indexes ( $4^{\text {th }}$ grade $)$ & Yes & Yes & Yes \\
\hline$N$ & 2431 & 1193 & 1238 \\
\hline$R^{2}$ & 0.289 & 0.274 & 0.282 \\
\hline
\end{tabular}

\section{Intervention of parents in application decision}

Another potential factor that could explain the role of early tracking on student selfconfidence is the intervention of parents. In general we assume that parents play an important role for decision to apply and there is an evidence that support this decision. While it is somewhat obvious why parents encourage their children to apply (enhanced educational and labor market opportunities derived from placement in the best schools, and with no material application cost), it is less obvious why other parents take the opposite approach, as it may appear to be irrational. Parental education per se does not play a role for the change in selfconfidence either boys or girls (see Table 3). Parents may not want their children to go to 
selective schools due to their preference for value transmission (parents prefer that their children have a similar education and experiences as themselves), the cost of stress of applying and then attending demanding schools, their unwillingness or inability to invest in private preparatory courses to train pupils in the exam process, or their belief that their children are not good enough or would not succeed in selective schools.

\section{Table 6}

Intervention of parents in interaction with the number of applicants in the class

\begin{tabular}{|c|c|c|c|}
\hline Self-confidence $\left(5^{\text {th }}\right.$ grade $)$ & $\begin{array}{l}(1) \\
\text { All }\end{array}$ & $\begin{array}{c}(2) \\
\text { Girls }\end{array}$ & $\begin{array}{c}(3) \\
\text { Boys }\end{array}$ \\
\hline Parents didn't want me apply $=1$ & $\begin{array}{c}0.045 \\
(0.038)\end{array}$ & $\begin{array}{c}0.061 \\
(0.060)\end{array}$ & $\begin{array}{c}0.020 \\
(0.049)\end{array}$ \\
\hline $\begin{array}{l}\text { Number of applicants ( } 0 \text { as contr } \\
\quad 1\end{array}$ & $\begin{array}{c}0.019 \\
(0.042)\end{array}$ & $\begin{array}{l}-0.013 \\
(0.068)\end{array}$ & $\begin{array}{c}0.039 \\
(0.054)\end{array}$ \\
\hline 2 & $\begin{array}{c}0.022 \\
(0.045)\end{array}$ & $\begin{array}{l}-0.034 \\
(0.072)\end{array}$ & $\begin{array}{c}0.076 \\
(0.057)\end{array}$ \\
\hline 3 & $\begin{array}{l}-0.044 \\
(0.047)\end{array}$ & $\begin{array}{l}-0.033 \\
(0.074)\end{array}$ & $\begin{array}{l}-0.072 \\
(0.059)\end{array}$ \\
\hline 4 & $\begin{array}{c}0.015 \\
(0.049)\end{array}$ & $\begin{array}{l}-0.072 \\
(0.078)\end{array}$ & $\begin{array}{c}0.082 \\
(0.062)\end{array}$ \\
\hline 5 & $\begin{array}{l}-0.015 \\
(0.040)\end{array}$ & $\begin{array}{l}-0.040 \\
(0.062)\end{array}$ & $\begin{array}{c}0.006 \\
(0.051)\end{array}$ \\
\hline $\begin{array}{l}\text { Parents }=1 * \text { number of applicant } \\
\quad 1\end{array}$ & $\begin{array}{l}-0.044 \\
(0.057)\end{array}$ & $\begin{array}{c}0.007 \\
(0.088)\end{array}$ & $\begin{array}{l}-0.080 \\
(0.074)\end{array}$ \\
\hline 2 & $\begin{array}{l}-0.064 \\
(0.062)\end{array}$ & $\begin{array}{l}-0.025 \\
(0.095)\end{array}$ & $\begin{array}{l}-0.091 \\
(0.081)\end{array}$ \\
\hline 3 & $\begin{array}{l}-0.020 \\
(0.061)\end{array}$ & $\begin{array}{l}-0.069 \\
(0.093)\end{array}$ & $\begin{array}{c}0.055 \\
(0.080)\end{array}$ \\
\hline 4 & $\begin{array}{l}-0.081 \\
(0.064)\end{array}$ & $\begin{array}{l}-0.063 \\
(0.098)\end{array}$ & $\begin{array}{l}-0.073 \\
(0.083)\end{array}$ \\
\hline 5 & $\begin{array}{l}-0.115^{* *} \\
(0.052)\end{array}$ & $\begin{array}{l}-0.094 \\
(0.079)\end{array}$ & $\begin{array}{l}-0.126^{*} \\
(0.068)\end{array}$ \\
\hline Individual characteristics & Yes & Yes & Yes \\
\hline Class characteristics & Yes & Yes & Yes \\
\hline Other Indexes ( $4^{\text {th }}$ grade $)$ & Yes & Yes & Yes \\
\hline $\begin{array}{l}N \\
R^{2}\end{array}$ & $\begin{array}{l}2244 \\
0.264\end{array}$ & $\begin{array}{l}1101 \\
0.258\end{array}$ & $\begin{array}{l}1143 \\
0.247\end{array}$ \\
\hline
\end{tabular}

Note: Standard errors in parentheses $\left({ }^{*} p<0.1,{ }^{* *} p<0.05,{ }^{* * *} p<0.01\right)$.

To take the explicit intervention of parents into account for pupils who did not apply (the great majority of the panel), we created a dummy variable indicating that their parents did not want them to apply, and then interacted the variable with the number of applicants in the 
class. The results, reported in Table 6, indicate that parents do influence their children in the face of a competitive environment, particularly boys in the most competitive classrooms. For example, comparing non-applying boys in the most competitive classes (5 applicants or more), those with discouraging parents have by $13 \%$ higher probability of experiencing a decline in self-confidence than boys without this parents' intervention. However, the intervention of parents seems to have no significant impact on girls' self-confidence.

\section{Table 7}

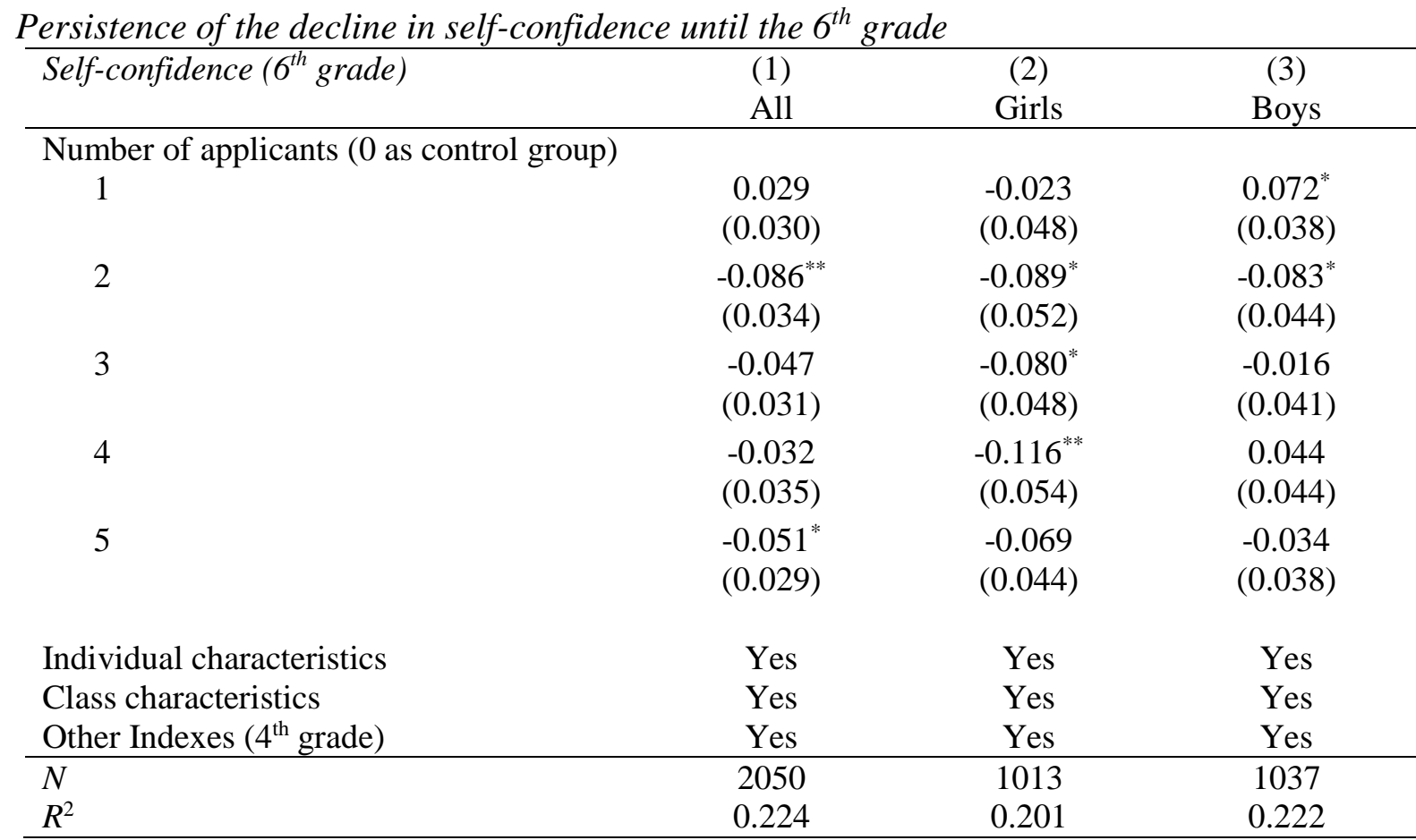

Note: Standard errors in parentheses $\left({ }^{*} p<0.1,{ }^{* *} p<0.05,{ }^{* * *} p<0.01\right)$.

\section{Persistence of the effect}

Using the same specification as for the main model in Table 3 (i.e. controlling for the number of applicants in class, $4^{\text {th }}$ grade self-confidence and other $4^{\text {th }}$ grade indexes as well as individual and class characteristics), we further test the persistence of the effect on pupils' self-confidence until the $6^{\text {th }}$ grade. The persistence of declines in self-confidence is policy relevant, as it would reveal possibly long-term effects on academic achievement. Our approach can eliminate the possibility of only a momentary change in pupils' self-assessment. The results of the persistence effect presented in Table 7 confirm the negative impact of the 
number of applicants in the classroom on the self-confidence of those who did not apply. Moreover, the magnitude of the effect on pupils' self-confidence in the $6^{\text {th }}$ grade is similar to the one in the previous grade, and again with significant impact only in the case of girls.

These results should be, however, taken with caution as not all fifth graders in our sample were followed in the $6^{\text {th }}$ grade. Hence, our subsample in the $6^{\text {th }}$ grade may not be representative and may induce sample selection bias in the results. Nevertheless, as the results are strongly significant and in line with the effects found in the main model, they can be taken as an indication of persistence of the effect to higher grades and of its possible impact on further schooling outcomes.

\section{Conclusion}

Early tracking is a feature of many educational systems around the globe, the typical aim of which is to sort pupils into homogeneous ability groups that may make it more efficient for students to learn and teachers to teach. Our goal is to not assess early tracking as such, but to examine the effect of the competitive application process inherent in early tracking systems on the self-confidence of students who do not apply to such selective schools. Our interest in changes in self-confidence derives from the role of self-confidence as a soft skill that can potentially impact future educational and occupational attainment, as well as a form of aversion to unequal outcomes of competition. To do this, we operationalize the competitive process in terms of the number of pupils who apply, and the number of admitted, in each classroom, while controlling for a variety of individual and contextual variables, including changes in GPA.

We first found that girls, but not boys, are inequality averse, in terms of experiencing a decline in self-confidence between the beginning and the end of their observation of the competition to selective schools. When we differentiate the number of applicants from the number of successful ones, we find that girls are particularly averse to the latter, i.e. by the 
unequal payoffs realized in the tracking process, rather than by the number of applicants per se. While boys seem to be affected by the competitive process net of the realized payoffs, in most predicted scenarios the net effect of competition on their self-confidence is rather zero. We also find that the gender difference in the decline in self-confidence, as well the degree of that decline, is persists between $5^{\text {th }}$ and $6^{\text {th }}$ grades, indicating that there could be longer term effects of early selection on students' self-confidence.

We believe that these results are relevant to the academic literature in a number of ways. As research increasingly examines the role of soft and hard skills on educational and occupational attainment, it will become increasingly important to understand the role of features of educational systems in shaping key traits like self-confidence in mathematics. Second, gender gaps in the attainment of academic degrees in STEM fields, and the policy goal of increasing women's participation in those fields, suggests it is crucially important to understand why girls might become less self-confident in STEM fields during the critical years of their academic development. And lastly, as scholars continue to debate the degree of inequality and efficiency in educational systems with varying types and degrees of tracking, we show that the role of tracking on the 'socioemotional' development of children warrants scholarly attention.

The results of our analysis come with a number of limitations and caveats. First, besides the grades given by teachers to students, we have little information about changes in teacher policy between the $4^{\text {th }}$ and $5^{\text {th }}$ grades. It is possible that changes in teacher policy, or changes in study materials, would influence students' self-confidence. That, however, would not explain why self-confidence would be so strongly influenced by the intensity of the competitive process. But if it could be shown that there are some unobserved teacher behaviors correlated to the intensity of competition, those unobservables could potentially explain some of the estimated effects we have found in this paper. That would not detract 
from our overall findings on the impact of early tracking on self-confidence, but would enable us to better differentiate the role of teachers during the competitive process from the competitive process itself.

Second, our study would benefit from an additional follow-up analysis. To what degree does early tracking impact self-confidence in later adolescent years, and how does that self-confidence impact latter educational aspirations and attainment? Given that we have a randomized panel of pre-treatment pupils along with their cognitive and non-cognitive skills, the results of this study would be enriched by a closer examination of the long-term effects of early-tracking competition.

\section{References}

Andreoni, J., \& Vesterlund, L. (2001). Which is the fair sex? Gender differences in altruism. Quarterly Journal of Economics, 293-312.

Andrews, J., \& Higson, H. (2008). Graduate employability, 'soft skills' versus 'hard' business knowledge: A European study. Higher education in Europe, 33(4), 411-422.

Authors. (2014). Kids in School.

Authors. (2016). Comparing schools.

Bandura, A. (1997). Self-efficacy: The exercise of control. New York, NY: Freeman.

Bandura, A. (2001). Social cognitive theory: An agentic perspective. Annual Review of Psychology, 52(1), 1-26.

Betts, J. R. (2011). The economics of tracking in education. In E. Hanushek, S. Machin, \& L. Woessmann (eds), Handbook of the Economics of Education (Vol. 3, pp. 341-381. Amsterdam, The Netherlands: North Holland.

Bolton, G. E., \& Ockenfels, A. (2006). Inequality aversion, efficiency, and maximin preferences in simple distribution experiments: comment. The American economic review, 96(5), 1906-1911.

Brunello, G., \& Checchi, D. (2007). Does school tracking affect equality of opportunity? New international evidence. Economic policy, 22(52), 782-861.

Buchmann, C., \& Park, H. (2009). Stratification and the formation of expectations in highly differentiated educational systems. Research in Social Stratification and Mobility, 27(4), 245-267.

Croson, R., \& Gneezy, U. (2009). Gender differences in preferences. Journal of Economic literature, 47(2), 448-474. 
Dean, D. J., \& Fleckenstein, A. (2007). Keys to success for women in science. In R. J. Burke \& M. C. Mattis (eds), Women and Minorities in Science, Technology, Engineering, and Mathematics: Upping the Numbers (pp. 28-46). Cheltenham, UK: Edward Elgar.

Eagly, A. H., \& Wood, W. (1999). The origins of sex differences in human behavior: Evolved dispositions versus social roles. American psychologist, 54(6), 408.

Eckel, C. C., \& Grossman, P. J. (1998). Are women less selfish than men?: Evidence from dictator experiments. The economic journal, 108(448), 726-735.

Engelmann, D., \& Strobel, M. (2004). Inequality aversion, efficiency, and maximin preferences in simple distribution experiments. The American Economic Review, 94(4), 857-869.

Fehr, E., \& Schmidt, K. M. (1999). A theory of fairness, competition, and cooperation. Quarterly journal of Economics, 817-868.

Fehr, E., Naef, M., \& Schmidt, K. M. (2006). Inequality aversion, efficiency, and maximin preferences in simple distribution experiments: Comment. The American economic review, 96(5), 1912-1917.

Fehr, E., Bernhard, H., \& Rockenbach, B. (2008). Egalitarianism in young children. Nature, 454(7208), 1079-1083.

Feingold, A. (1994). Gender differences in personality: a meta-analysis. Psychological bulletin, 116(3), 429.

Gamoran, A., \& Mare, R. D. (1989). Secondary school tracking and educational inequality: Compensation, reinforcement, or neutrality?. American journal of Sociology, 1146-1183.

Gneezy, U., Niederle, M., \& Rustichini, A. (2003). Performance in competitive environments: Gender differences. Quarterly journal of Economics, 118(3), 1049-1074.

Greger, D. (2015). The Czech Republic: 25 years of educational transformation and growing inequalities 1989-2014. In. T. Corner (ed), Education in the European Union: Post-2003 Member States (75-92). London, UK: Bloomsbury.

Hanushek, E. A. (2006). Does educational tracking affect performance and inequality? Differences-in-differences evidence across countries. The Economic Journal, 116(510), C63-C76.

Heckman, J. J., \& Kautz, T. (2012). Hard evidence on soft skills. Labour economics, 19(4), 451-464.

Heubert, J. P., \& Hauser, R. M. (Eds.). (1998). High stakes: Testing for tracking, promotion, and graduation. National Academies Press.

Kinzie, M. B., Delcourt, M. A., \& Powers, S. M. (1994). Computer technologies: Attitudes and self-efficacy across undergraduate disciplines. Research in higher education, 35(6), 745-768.

Louis, R. A., \& Mistele, J. M. (2012). The differences in scores and self-efficacy by student gender in mathematics and science. International Journal of Science and Mathematics Education, 10(5), 1163-1190. 
Marra, R. M., Rodgers, K. A., Shen, D., \& Bogue, B. (2009). Women engineering students and self-efficacy: A multi-year, multi-institution study of women engineering student self-efficacy. Journal of Engineering Education, 98(1), 27.

Montgomery, H. (2005). Gendered childhoods: a cross disciplinary overview. Gender and Education, 17(5), 471-482.

Niederle, M., \& Vesterlund, L. (2007). Do women shy away from competition? Do men compete too much?. The Quarterly Journal of Economics, 1067-1101.

Niederle, M., \& Vesterlund, L. (2010). Explaining the gender gap in math test scores: The role of competition. The Journal of Economic Perspectives, 24(2), 129-144.

Niederle, M., \& Vesterlund, L. (2011). Gender and competition. Annu. Rev. Econ., 3(1), 601630.

Norman, M., \& Hyland, T. (2003). The role of confidence in lifelong learning. Educational studies, 29(2-3), 261-272.

Phillips, D. (2000). The enduring nature of the tripartite system of secondary schooling in Germany: Some explanations. British Journal of Educational Studies, 48(4), 391-412.

Dacre Pool, L., \& Sewell, P. (2007). The key to employability: developing a practical model of graduate employability. Education + Training, 49(4), 277-289.

Shavit, Y. (Ed.). (2007). Stratification in higher education: A comparative study. Stanford, CA: Stanford University Press.

Smith, R. H., \& Kim, S. H. (2007). Comprehending envy. Psychological bulletin, 133(1), 46.

Steinbeis, N., \& Singer, T. (2013). The effects of social comparison on social emotions and behavior during childhood: The ontogeny of envy and Schadenfreude predicts developmental changes in equity-related decisions. Journal of Experimental Child Psychology, 115(1), 198-209.

Usher, E. L., \& Pajares, F. (2009). Sources of self-efficacy in mathematics: A validation study. Contemporary educational psychology, 34(1), 89-101.

Van de Werfhorst, H. G., \& Mijs, J. J. (2010). Achievement inequality and the institutional structure of educational systems: A comparative perspective. Annual review of sociology, $36,407-428$.

Woessmann, L. (2010). Institutional determinants of school efficiency and equity: German states as a microcosm for OECD countries. Jahrbücher für Nationalökonomie und Statistik, 230(2), 234-270.

Zimmerman, B. J. (2000). Self-efficacy: An essential motive to learn. Contemporary educational psychology, 25(1), 82-91. 


\section{Appendix}

Appendix 1: Variation in the number of pupils who applied

\begin{tabular}{lc}
\hline $\begin{array}{l}\text { Number of applicants } \\
\text { (on class level) }\end{array}$ & $(1)$ \\
\hline $\begin{array}{l}\text { Number of available seats in } \\
\text { district }\end{array}$ & $1.048^{* * * *}$ \\
& $(0.271)$ \\
Math score $\left(4^{\text {th }}\right.$ grade) & $0.077^{* * *}$ \\
& $(0.027)$ \\
GPA ( $4^{\text {th }}$ grade) & $-0.125^{* * *}$ \\
& $(0.047)$ \\
University education - father & 0.006 \\
& $(0.106)$ \\
University education - mother & $0.301^{* *}$ \\
& $(0.129)$ \\
Boy=1 & -0.110 \\
& $(0.070)$ \\
Age & 0.065 \\
& $(0.072)$
\end{tabular}

\begin{tabular}{lc} 
Other Indexes $\left(4^{\text {th }}\right.$ grade $)$ & Yes \\
\hline$N$ & 216 \\
$R^{2}$ & 0.432 \\
Adj. $R^{2}$ & 0.402 \\
\hline Note: Standard errors in parentheses $\left(^{*} p<0.1,{ }^{* *} p<0.05,{ }^{* * * *} p<0.01\right)$.
\end{tabular}


Appendix 2: Change in self-confidence of pupils who did not apply, LPM and marginal effects after Probit, full specification.

\begin{tabular}{|c|c|c|c|c|c|c|}
\hline \multirow[t]{2}{*}{ Self-confidence $\left(5^{\text {th }}\right.$ grade $)$} & \multicolumn{3}{|c|}{ LPM } & \multicolumn{3}{|c|}{ Probit } \\
\hline & All & Girls & Boys & All & Girls & Boys \\
\hline \multicolumn{7}{|l|}{ Number of applicants } \\
\hline \multirow[t]{2}{*}{1} & -0.014 & -0.024 & -0.006 & -0.014 & -0.030 & -0.003 \\
\hline & $(0.027)$ & $(0.042)$ & $(0.035)$ & $(0.027)$ & $(0.041)$ & $(0.034)$ \\
\hline \multirow[t]{2}{*}{2} & -0.016 & -0.064 & 0.036 & -0.016 & -0.069 & 0.034 \\
\hline & $(0.030)$ & $(0.046)$ & $(0.039)$ & $(0.029)$ & $(0.045)$ & $(0.037)$ \\
\hline \multirow[t]{2}{*}{3} & $-0.060^{* *}$ & $-0.090^{* *}$ & -0.034 & $-0.058^{* *}$ & $-0.087^{* *}$ & -0.039 \\
\hline & $(0.029)$ & $(0.044)$ & $(0.038)$ & $(0.029)$ & $(0.043)$ & $(0.038)$ \\
\hline \multirow[t]{2}{*}{4} & -0.032 & $-0.115^{* *}$ & 0.043 & -0.033 & $-0.115^{* *}$ & 0.040 \\
\hline & $(0.032)$ & $(0.049)$ & $(0.041)$ & $(0.031)$ & $(0.048)$ & $(0.039)$ \\
\hline \multirow[t]{2}{*}{5 or more } & $-0.069^{* * * *}$ & $-0.085^{* *}$ & -0.056 & $-0.071^{* * * *}$ & $-0.088^{* *}$ & $-0.060^{*}$ \\
\hline & $(0.026)$ & $(0.039)$ & $(0.035)$ & $(0.026)$ & $(0.039)$ & $(0.035)$ \\
\hline \multicolumn{7}{|l|}{ Other indexes $-4^{\text {th }}$ grade } \\
\hline \multirow[t]{2}{*}{ Self-confidence } & $0.113^{* * *}$ & $0.129^{* * *}$ & $0.074^{*}$ & $0.076^{* * *}$ & $0.114^{* * *}$ & 0.025 \\
\hline & $(0.027)$ & $(0.038)$ & $(0.040)$ & $(0.025)$ & $(0.036)$ & $(0.035)$ \\
\hline \multirow{2}{*}{ Learn quickly math } & $-0.074^{* * *}$ & $-0.099^{* * * *}$ & $-0.048^{* * * *}$ & $-0.064^{* * * *}$ & $-0.089^{* * *}$ & $-0.042^{* * * *}$ \\
\hline & $(0.012)$ & $(0.018)$ & $(0.016)$ & $(0.011)$ & $(0.017)$ & $(0.014)$ \\
\hline \multirow[t]{2}{*}{ Learn quickly science } & 0.016 & 0.018 & 0.015 & 0.013 & 0.015 & 0.011 \\
\hline & $(0.012)$ & $(0.018)$ & $(0.015)$ & $(0.011)$ & $(0.018)$ & $(0.015)$ \\
\hline \multirow[t]{2}{*}{ Do well science } & -0.004 & -0.009 & -0.000 & -0.004 & -0.010 & 0.001 \\
\hline & $(0.012)$ & $(0.019)$ & $(0.016)$ & $(0.012)$ & $(0.019)$ & $(0.016)$ \\
\hline \multirow[t]{2}{*}{ Enjoy math } & $-0.102^{* * * *}$ & $-0.098^{* * *}$ & $-0.107^{* * *}$ & $-0.093^{* * *}$ & $-0.096^{* * *}$ & $-0.092^{* * * *}$ \\
\hline & $(0.011)$ & $(0.016)$ & $(0.014)$ & $(0.010)$ & $(0.015)$ & $(0.012)$ \\
\hline \multicolumn{7}{|l|}{ Individual characteristics } \\
\hline \multirow[t]{2}{*}{$4^{\text {th }}$ grade math score } & $0.061^{* * *}$ & $0.053^{* * *}$ & $0.069^{* * *}$ & $0.063^{* * *}$ & $0.053^{* * *}$ & $0.072^{* * *}$ \\
\hline & $(0.011)$ & $(0.017)$ & $(0.014)$ & $(0.011)$ & $(0.016)$ & $(0.014)$ \\
\hline \multirow[t]{2}{*}{$4^{\text {th }}$ grade GPA } & $-0.127^{* * * *}$ & $-0.126^{* * * *}$ & $-0.126^{* * *}$ & $-0.118^{* * *}$ & $-0.125^{* * *}$ & $-0.104^{* * * *}$ \\
\hline & $(0.016)$ & $(0.025)$ & $(0.020)$ & $(0.015)$ & $(0.024)$ & $(0.018)$ \\
\hline \multirow[t]{2}{*}{ University education - father } & 0.003 & -0.031 & 0.041 & 0.000 & -0.028 & 0.032 \\
\hline & $(0.026)$ & $(0.040)$ & $(0.033)$ & $(0.026)$ & $(0.039)$ & $(0.033)$ \\
\hline \multirow[t]{2}{*}{ University education - mother } & -0.015 & 0.008 & -0.048 & -0.013 & 0.002 & -0.040 \\
\hline & $(0.027)$ & $(0.041)$ & $(0.037)$ & $(0.027)$ & $(0.040)$ & $(0.037)$ \\
\hline \multirow[t]{2}{*}{ Boy $=1$} & $0.115^{* * *}$ & - & - & $0.115^{* * * *}$ & - & - \\
\hline & $(0.017)$ & & & $(0.017)$ & & \\
\hline \multirow[t]{2}{*}{ Age } & -0.029 & -0.042 & -0.021 & -0.026 & -0.041 & -0.018 \\
\hline & $(0.020)$ & $(0.033)$ & $(0.026)$ & $(0.020)$ & $(0.032)$ & $(0.025)$ \\
\hline Class characteristics ( $4^{\text {th }}$ grade & & & & & & \\
\hline Class GPA & -0.023 & 0.037 & $-0.090^{* *}$ & -0.019 & 0.044 & $-0.086^{*}$ \\
\hline & $(0.035)$ & $(0.054)$ & $(0.046)$ & $(0.035)$ & $(0.053)$ & $(0.044)$ \\
\hline Class score - math & $-0.080^{* * * *}$ & $-0.061^{*}$ & $-0.097^{* * *}$ & $-0.081^{* * * *}$ & $-0.060^{*}$ & $-0.097^{* * * *}$ \\
\hline & $(0.023)$ & $(0.035)$ & $(0.031)$ & $(0.023)$ & $(0.035)$ & $(0.031)$ \\
\hline Class self-confidence & 0.010 & 0.046 & -0.038 & 0.018 & 0.039 & -0.022 \\
\hline & $(0.086)$ & $(0.126)$ & $(0.117)$ & $(0.083)$ & $(0.117)$ & $(0.117)$ \\
\hline Class count & 0.000 & 0.002 & -0.002 & 0.000 & 0.002 & -0.001 \\
\hline & $(0.002)$ & $(0.003)$ & $(0.002)$ & $(0.002)$ & $(0.003)$ & $(0.002)$ \\
\hline$N$ & 2479 & 1216 & 1263 & 2479 & 1216 & 1263 \\
\hline$R^{2}$ & 0.265 & 0.255 & 0.248 & & & \\
\hline
\end{tabular}




\begin{abstract}
Abstrakt
Systém rozřazování žáků do osmiletých gymnázií v jedenácti letech přirozeně vytváří dvě skupiny: studenti, kteří se připravují na prijímací zkoušky a ostatní, kteří se rozhodli se nepřihlásit na osmiletá gymnázia. Využitím dat z TIMSS a z navazujícího výběrového šetření v České republice ukazujeme, že soutěživé prostředí má negativní dopad na sebevědomí těch žáků, kteří se nehlásí na gymnázium, ale mají ve třídě spolužáky, kteří se na gymnázium hlásí. Konkrétně zjištujeme, že dívky, které se nehlásí na gymnázia, vykazují pokles v sebevědomí o 11 procent, a to v prípadě, že mají čtyři spolužáky, kteří se hlásí a jsou úspěšní v prijij́macích zkouškách. $V$ tomto výzkumu se soustředíme na sebevědomí v matematice, protože současná literatura tvrdí, že sebevědomí v matematice je př́mo korelováno s motivací studovat technické a prírodovědné obory a také se samotnou výkoností v těchto předmětech. Naše výsledky též ukazují, že pokles sebevědomí u dívek je dlouhotrvající, což dále implikuje, že často pozorované genderové rozdíly mohou být výsledkem kompetitivního prostředí ve vzdělávacím systému.
\end{abstract}




\section{Working Paper Series}

ISSN 1211-3298

Registration No. (Ministry of Culture): E 19443

Individual researchers, as well as the on-line and printed versions of the CERGE-EI Working Papers (including their dissemination) were supported from institutional support RVO 67985998 from Economics Institute of the CAS, v. v. i.

Specific research support and/or other grants the researchers/publications benefited from are acknowledged at the beginning of the Paper.

(c) Miroslava Federičová, Filip Pertold, and Michael L. Smith, 2016

All rights reserved. No part of this publication may be reproduced, stored in a retrieval system or transmitted in any form or by any means, electronic, mechanical or photocopying, recording, or otherwise without the prior permission of the publisher.

Published by

Charles University, Center for Economic Research and Graduate Education (CERGE)

and

Economics Institute of the CAS, v. v. i. (EI)

CERGE-El, Politických vězňů 7, 11121 Prague 1, tel.: +420 224005 153, Czech Republic.

Printed by CERGE-EI, Prague

Subscription: CERGE-EI homepage: http://www.cerge-ei.cz

Phone: + 420224005153

Email: office@cerge-ei.cz

Web: http://www.cerge-ei.cz

Editor: Jan Zápal

The paper is available online at http://www.cerge-ei.cz/publications/working_papers/.

ISBN 978-80-7343-381-9 (Univerzita Karlova, Centrum pro ekonomický výzkum a doktorské studium)

ISBN 978-80-7344-397-9 (Národohospodářský ústav AV ČR, v. v. i.) 
CERGE-EI

P.O.BOX 882

Politických vězňů 7

11121 Praha 1

Czech Republic http://www.cerge-ei.cz 